\title{
Development and Validation of a Measure of Leader Rapport Management: The LRM Scale
}

\author{
Charles D. White \\ Longwood University \\ Kim Sydow Campbell \\ The University of Alabama \\ K. Michele Kacmar \\ The University of Alabama
}

\begin{abstract}
The purpose of this study is to develop and validate a scale to measure the construct of leadership rapport management (LRM) and demonstrate its potential impact on relationships between supervisors and subordinates. A brief review of the construct is presented along with its anticipated theoretical and empirical relationships with constructs that might be closely related such as LMX, perceived supervisor support, trust, and interactional justice. Construct definitions are developed and items for an LRM measure are evaluated using a three-sample validation study. Exploratory and confirmatory factor analysis results reveal a three-factor model of LRM and preliminary evidence of reliability and construct validity is provided.
\end{abstract}

\section{Introduction}

At least since the 1970s, there has been clear evidence that managers spend a great deal of their time in face-to-face exchanges with subordinates as part of their organizational role (Mintzberg, 1973). Unfortunately, Basch and Fisher (2000) found that ninety percent of the interactions at an international hotel chain that led to employees' feeling frustrated, disappointed, angry, sad, disgusted, or hurt were those between employees and their supervisors. As further evidence of the discrepancy between leaders' actual and needed interaction skills, an Academy of Management/Training magazine survey of leadership development programs finds that, of all required leadership skills, communication is of most value to organizations. Unfortunately, the survey also found that, of all required leadership skills, communication showed the largest gap between importance to the organization and current competency (Delahoussaye, 2001a, 2001b).

Research has established that communication satisfaction is crucial to employee productivity (Clampitt \& Downs, 1993), job satisfaction (Wheeless, Wheeless, \& Howard, 1984), job performance (Pincus, 1986), and organizational effectiveness (Tubbs \& Hain, 1979). A recent study finds clear evidence to support a link between 
employee communication satisfaction and leader-member relations. Specifically, the researchers concluded that the way to increase overall level of communication satisfaction is to develop and maintain higher-quality exchanges with as many subordinates as possible (Mueller \& Lee, 2002).

LMX has well documented desirable outcomes associated with high quality exchanges such as employee performance (Graen, Novak, \& Sommerkamp, 1982), satisfaction (Graen, Novak et al., 1982) and commitment (Nystrom, 1990). See Schriesheim, Castro, \& Cogliser [1999] and Gerstner \& Day [1997] for major reviews of LMX research. These are increasingly important outcomes given the inconsistent nature of modern employment relationships (Ng, Butts, Vandenberg, DeJoy, \& Wilson, 2006). Commitment, particularly, has been shown to be an important predictor of favorable employee attitudes and behaviors (Riketta, Van Dick, 2005; Meyer, Stanley, Herscovitch, \& Topolnytsky, 2002). Yet, despite the importance of these outcomes, much less research has been conducted on the specific leader behaviors that influence the development of high quality exchanges between leaders and subordinates (Burns \& Otte, 1999). Despite the numerous theoretical and practical contributions of LMX theory in predicting employee behaviors, Dienesch and Liden (1986) have acknowledged that we do not know what specific behaviors take place between a leader and a subordinate that predict the quality of exchange. Previous researchers have suggested that addressing the behavioral components in the initial development of LMX would be the most important way to advance research (Burns \& Otte, 1999). In addition, Gerstner and Day (1997) state that research focusing on the development of high quality dyadic relationships and related management training models would be a valuable addition to current models.

In this paper, we contend that the sociolinguistic concept of rapport management may provide a valuable tool in the search for behaviors that contribute to the development and maintenance of high quality leader-member exchanges and that therefore enhance critical outcomes like trust and interactional justice.

\section{Defining Rapport Management}

\section{Rapport}

For the current study, rapport is defined as the level of relatedness felt between participants in an interaction (Gremler \& Gwinner, 2000). It is important to note that, based on this definition, rapport cannot exist between two individuals who have not interacted. This differentiates the notion of rapport from feelings of connectedness or distance resulting from the roles or reputations of participants or various personal prejudices which influence the relationship. These factors may influence the development of rapport in a relationship; however, the focus of the current study is on elements of rapport that can be directly influenced by participant behavior, especially leader behavior, in a leader-subordinate relationship.

\section{Rapport Management}


Drawing on Erving Goffman's concept of public self-image or "face" $(1959,1967)$, contemporary sociolinguistic research posits that the level of personal connection in an interaction is related to the interactants' fundamental and universal desires and rights related to their public self-image. More specifically, Brown and Levinson (1987) establish a theory of politeness with two aspects: autonomy (which they call negative face) is "the want of every competent adult member that his actions be unimpeded by others," while ego (which they call positive face) is "the want of every member that his wants be desirable to at least some others" (p. 62). We follow Campbell (2006) in avoiding the term "face" in the remainder of this paper. However, the concept applies in the leader-member exchange as follows. When a leader interacts with a subordinate, saying Get that report to me by Friday, the subordinate's desire for autonomy is threatened, leading to a perception of the leader's behavior as impolite and lowering the level of rapport between the two individuals. Similarly, when a leader interacts with a subordinate, saying Your production is down this quarter, the subordinate's ego wants are threatened. The ability to "manage" others' wants/rights during interaction is a critical social skill because of its impact on rapport (Campbell, White, \& Johnson, 2003).

Spencer-Oatey $(2000,2002)$ extended this line of sociolinguistic research and coined the term, "rapport management," which refers to the use of language to manage social relations by attending to interactants' desires and rights. In this context, rapport management refers to whether or not interpersonal communication behavior works to increase/decrease rapport, regardless of a goal-oriented desire to do so. SpencerOatey $(2000,2002)$ expanded prior theory by postulating that these wants/rights apply at both the individual and group levels, thus producing four categories of public selfimage involved in rapport management: ego wants (individual), ego wants (group), autonomy rights (individual), and association rights (group). Definitions of these desires/rights are provided in Table 1.

Table 1

Dimensions of rapport management

Dimension Definition

Individual Ego Wants An interactant's desire to be valued as an individual

Group Ego Wants An interactant's desire to have his/her social roles valued

Autonomy Rights An interactant's right to not be imposed upon unfairly

Association Rights An interactant's right to the time and attention of another

Note: Adapted from Campbell et al. (2003).

While some previous research has explored the concept of ego/autonomy within the context of workplace communication (Campbell, White \& Durant, 2007; Campbell et al., 2003; Fairhurst \& Chandler, 1989; Morand, 2000), there has been no attempt to develop a scale for measuring leader rapport management (LRM).

\section{Connecting Leadership and Communication}


Quinn, Hildebrandt, Rogers, \& Thompson (1991) clarify the variety of values demonstrated by (or purposes for) managerial communication. Campbell, White, and Johnson (2003) argue that two of these are transformational, hence particularly important in leadership: consultative communication, which stimulates change, and relational communication, which builds trust. Leadership research has long acknowledged the importance of relationship building with subordinates. Terminology within these theories sometimes makes this explicit: for example, the TannebaumSchmidt Continuum refers to "relationship-based power" in defining Theory $Y$ (Tannebaum \& Schmidt, 1973), and Fiedler's Contingency theory refers to "leadermember relations" (Fiedler, 1967). Other times, terminology within leadership theory has been implicitly relationship-focused. More specifically, Michigan leadership studies refer to leader support and interaction facilitation and Ohio State leadership studies refer to consideration and sensitivity to subordinates (Hughes, Ginnett, \& Curphy, 2009); Blake and McCanse's Leadership Grip refers to "concern for people" (Blake \& McCanse, 1991); and House-Mitchell Path-Goal theory refers to "consideration behavior" (House, 1971). One of the more influential leadership theories, leader member exchange (LMX), focused attention even more clearly on relationship building by highlighting the dyadic relationship (i.e., exchange) between a leader and his or her subordinates (Graen \& Cashman, 1975).

\section{$\underline{\text { LRM and LMX }}$}

Our understanding of the quality of interpersonal treatment between leaders and members has been significantly advanced through studies of LMX (Graen, 1976; Graen \& Uhl-Bien, 1995), a construct that has been linked to communication satisfaction (Mueller \& Lee, 2002). According to LMX theory, leaders develop different relationships with subordinates, resulting in two groups of employees. Members of the "in-group" have working relationships with the leader characterized by trust, mutual influence, support, and formal/informal rewards, whereas the "out-group" employees have relationships with the leader characterized by the use of formal authority, low trust, and limited support and rewards. Research has indicated that high-quality (i.e., in-group) exchange relationships involve showing mutual respect and concern (Dienesch \& Liden, 1986; Whitener, Brodt, Korsgaard, \& Werner, 1998) and are associated with greater leader attention, support, and sensitivity (Liden \& Graen, 1980), greater member satisfaction and lower turnover (Graen, Liden, \& Hoel, 1982), and better member performance (Graen, Novak et al., 1982).

Some studies have helped to clarify how leader behavior impacts the leader-member exchange. For example, Erdogan and Liden (2002) suggest that expectancy theory may help explain why employees who have high quality exchanges with their supervisor have better responses to delegation by the supervisor (Schriesheim, Neider, \& Scandura, 1998) due to increased performance efficacy. In addition, Masterson, Lewis, Goldman, and Taylor (2000) found that leaders who engage in behaviors that increase perceptions of interactional justice also increase perceptions of LMX quality. Yet more recently, researchers have suggested that fundamental questions regarding subordinate expectations have yet to be addressed in LMX research (Huang, Wright, Chiu, \& Wang, 
2008).

In order to address this challenge, leadership research may benefit from studies which shed light on specific leader behaviors that influence the development of effective leader member exchanges and how those behaviors influence subordinate perceptions. To better understand such leader behaviors, Burns and Otte (1999) suggest the use of literature from other fields that deal with relationships. Recent studies in communicator style continue to shed light on specific communication behaviors in leadership settings (Snavely \& McNeill, 2008). Further, Lagace (1990) suggested that research in communication style and social interaction style may provide a means of determining how the LMX relationship develops.

Rapport management researchers identify a number of specific communication techniques that establish a sense of personal connection (Campbell et al. 2003). Most of this work has focused on behaviors that mitigate or manage the negative effects of rapport "threatening" messages. For example, leaders cannot avoid delivering threatening messages to subordinates when they must provide negative feedback, enforce workplace policies, or deal with workplace conflict, but leaders can manage the negative effects of threatening messages on their relationship with subordinates, thereby increasing their chances of building or maintaining rapport and high quality leader-member exchanges. Questions still remain as to how leaders can improve the development of the quality of their relationships with subordinates (Burns \& Otte, 1999). Liden, Wayne, and Stilwell (1993) found that affective variables (liking and perceived similarity) were very influential in the early stages of the LMX development. Because of its emphasis on tending others' desires/rights, rapport management is expected to signal respect and concern for subordinates and therefore be influential in the development of high-quality exchanges between leaders and subordinates. Leaders' management of rapport, as perceived by subordinates, is expected to influence the overall quality of the relationship between the leader and the subordinate. Particularly, however, the quality of the leader-member exchange may be most impacted by the leader's management of the subordinate's association rights which are based on a subordinate's expectations regarding time and attention from the leader. Leaders who more effectively provide time and attention to subordinates, should increase the likelihood of developing high quality exchanges with those subordinates. Conversely, it is highly unlikely that leaders who neglect subordinate's rights to the leader's time and attention will be able to effectively establish high-quality exchanges with subordinates. Thus, we suggest that rapport management will be positively related. Formally stated:

\section{Hypothesis 1: LRM will be positively related to $L M X$.}

\section{$\underline{\text { LRM and Supervisor Support }}$}

Perceived supervisor support has been defined by Eisenberger, Stinglhamber, Vandenberghe, Sucharski, and Rhoades (2002) as "general views concerning the degree to which supervisors value their contributions and care about their well-being" (p. 565). Some have called communication that builds relationships supportive 
communication (Whetton \& Cameron, 1995). Fairhurst and Chandler (1989) noted differences in supportive communication between in-group and out-group members using the LMX model. Rapport management may provide a means of interpreting these differences by serving as a signal to subordinates that the leader is respectful of the dignity and value of the subordinate and will not use his/her position of authority to neglect the needs of the subordinate. Leaders are influenced not only by the urgency of an organizational goal but also by their awareness of the effect of their disagreement on their relationships with subordinates. These influences should lead them to communicate their messages using a rapport management strategy to mitigate rapport threats. In this case, the leader's mitigation of the threat relies upon paying explicit attention to the subordinate's group ego wants. Leaders' use of such a strategy is indicative of their understanding and support of the public self-image of the subordinate. All four dimensions of leader rapport management are expected to be related to subordinate perceptions of supervisor support.

Hypothesis 2: LRM will be positively related to perceived supervisor support.

\section{$\underline{\text { LRM and Trust }}$}

Dienesch and Liden (1986) suggested that a key component in building high quality LMX appears to be the development of interpersonal trust that goes beyond the formal employment contract. For the current research, trust is defined as a willingness to be vulnerable to another based on the expectation of favorable outcomes for the trusting party (Mayer, Davis, \& Schoorman, 1995). Over time, continued leader-subordinate interaction in which the leader uses rapport management strategies to tend to the subordinate's wants/rights may lead to increased levels of trust toward the leader. It has been suggested that trust is based on evidence of trustworthiness under specific circumstances and is developed through reliable role performance (McAllister, 1995). In addition, trust also may consist of emotional bonds and is developed through continued benevolent interaction (McAllister, 1995). Effective rapport management is expected to signal benevolence, defined as a manager's concern for the welfare of employees (Mayer \& Davis, 1999). Leaders who effectively demonstrate rapport management also may signal reliability due to the level of awareness required to attend to potential threats to the subordinate's public self-image. To the extent that rapport management is interpreted as a signal of reliability, benevolence, and concern, it is expected to positively relate to trust. Thus, we suggest that:

Hypothesis 3: LRM will be positively related to trust.

\section{$\underline{\text { LRM and Justice }}$}

Interactional justice is based on the idea that organizational members perceive interactions with superiors as being just or unjust and that these perceptions impact a number of important organizational outcomes such as commitment (Ambrose \& Schminke,2003; Li \& Butler, 2004; Thompson \& Heron, 2005), reduced stress (Greenberg, 2004), and reduced egocentric bias (Leung, Tong, \& Ho, 2004). Bies and 
Moag (1986) noted that the manner in which organizational procedures are implemented is an important factor in perceptions of justice. In addition, Rupp and Cropanzano (2002) suggested that "the interpersonal treatment one receives from a supervisor may be the critical variable" that "impacts both supervisory and organizationally relevant variables" (p. 938). Because rapport management theory captures behaviors that indicate sensitivity to subordinate's wants/rights and that reduce subordinate perceptions of threat and/or disrespect, rapport management may represent a potential source for increasing our understanding of how subordinates judge the justice of interpersonal interactions. For example, individual ego wants are closely associated with individual self-esteem, the sense that we are appreciated and approved of by others. Thus, when leaders criticize, they threaten the subordinate's ego. The resulting perception of injustice is motivated by the lowering of one's worth, credibility, dignity, honor, reputation, or competence. In addition, ignoring or damaging the member's ego wants signals disrespect, a characteristic of interactional injustice (Bies \& Moag, 1986). Based on these notions, a leader's rapport management behavior is expected to be significantly related to subordinate perceptions of interactional justice.

Hypothesis 4: LRM will be positively related to perceptions of interactional justice.

Unfortunately, rapport management as a means of assessing leadership behavior remains conceptually and empirically underdeveloped. One reason for this may be that, although others have measured the degree of rapport between individuals (e.g., LaBahn, 1996), no scale exists to measure the antecedent behaviors that influence the level of rapport and can, therefore, be managed. The purpose of the current work is to begin to fill this void by developing and testing a measure of leader rapport management using a multiple study validation procedure.

\section{Part 1: LRM Scale Development}

A three-stage process of scale development, including item generation, scale development, and scale evaluation (Hinkin, 1995), was used in this research.

\section{$\underline{\text { Item Generation }}$}

Potential items were developed by applying the four aspects of public self-image discussed above (Spencer-Oatey, 2000) to a selection of workplace narratives. The narratives were originally gathered for a study involving anger and justice in which respondents above the age of 30 with at least 5 years of work experience were asked to describe, in their own words, an incident at work that made them angry (Kiewitz, 2002); the narratives were also used in a qualitative research study focused on subordinate perceptions of injustice and the failure of leader to manage rapport (Campbell, White \& Durant, 2007).

For development of the LRM scale, three different coders independently assigned four categories of rapport management violations (i.e., threats to individual and group ego wants, autonomy rights, and association rights) to the 108 written narratives involving 
injustice perpetrated by leaders. The coders were faculty and doctoral student researchers who specialize in the areas of communication and, specifically, rapport management and have published research in these areas. Coding allowed for multiple responses per described incident as a single story might involve no violation of rapport management, violation of a single rapport management category, or violation of some combination of the four categories.

Of the 108 narratives, all three coders agreed on all four categories of rapport management codes for 64 (59\%) incidents; two of three coders agreed for an additional $42(39 \%)$ incidents for an average percent agreement for all rapport management coding of $79.8 \%$. Interrater reliability calculated using Cohen's kappa (Cohen, 1960) was high (.774) for individual ego wants, moderate (.514) for group ego wants and (.548) for autonomy rights, and low (.274) for association rights. This suggested that rapport management theory was worth exploring as an interpretive schema for development of a scale. We opted to continue investigating the value of all four rapport management categories, including association rights, to maintain consistency with established theory.

Our next step was to evaluate the narratives within each category to develop items representative of each dimension. Below we outline some examples of the narratives, corresponding rapport management coding categories, and the sample items based on those narratives. In $38(35 \%)$ of the108 narratives describing anger-inducing situations that involved a leader, the coders found evidence of violations of individual ego wants, primarily including stories about leaders who criticized subordinates unfairly. In such situations, the subordinate's anger (and perception of injustice) was motivated by a sense of loss to his/her worth, credibility, dignity, honor, reputation, or competence based on the leader's behavior toward him/her. One of those narratives appears below:

Narrative \#137: I came in at least 20 min early every morning. One morning I came at 8:05 and the "bitch" just started in about being late. She was all over me about being to work on time, and I just ate it up. It pissed me off to no end that it didn't matter about how early I came in, but it did matter when I came in late. So, I just kept coming in late.

Based on the rapport management literature and the sample narratives coded as ego wants violations, items were generated to represent rapport management success (My supervisor is considerate of my feelings) and failure (My supervisor criticizes me).

In $9(8 \%)$ of the narratives, like the one reprinted below, the coders found violations of group ego wants:

Narrative \#148: A time when I feel angry at work is more or less every day. The head of my department that ironically knows the very least about my job or anyone else's in the department telling us as a whole we aren't doing things right or "up to par" so to speak. If we have problems or questions and we take them to him, he usually looks dumbfounded and cannot provide an answer. He also 
makes derogatory remarks towards females in the office and their work apparel.

In this narrative, the subordinate's anger is prompted by the leader's treatment of the entire workgroup, especially other females. Because the subordinate identifies with these groups, her ego was threatened. Items were generated to assess a leader's success (My supervisor recognizes the importance of my role in the department/organization) and failure (My supervisor makes members of my workgroup look bad in front of others) in managing rapport with a subordinate.

In $33(31 \%)$ of the narratives, the coders found autonomy rights violations, like the one below:

Narrative \#230: Once my boss called me on a Sunday afternoon. He asked me to come to work for a few hours. To me, Sundays are for relaxation. I had no plans for the afternoon and I was just relaxing in shorts and a t-shirt. He called without any prior notice and asked me to come to work. I can't really say no to the boss because then I'm afraid he would hold it against me. I was really frustrated and mad because he had complete control over my day at that point.

The subordinate's narrative makes it clear that his/her anger and sense of injustice in this case were prompted by the fact that the leader imposed on the subordinate's personal time without offering the subordinate any real opportunity to refuse. Again, items were generated to assess a leader's success (My supervisor is considerate of my time) and failure (My supervisor does not give me the autonomy I need to do my job) to manage rapport.

In $14(13 \%)$ of the narratives, the coders found association rights violations, which reflect our sense of entitlement to be included in the activities of the groups with which we identify, including conversations and discussions about issues that concern us. Some narratives mention a lack of listening as in the example below:

Narrative \#172: I usually get mad at work when I am not listened to. It happens a lot when my views are overlooked and no one pays attention to my views. Other than that I love my job.

The subordinate's anger and sense of injustice in this case were prompted by the fact that the leader ignored the subordinate's opinion. The final items were generated to assess a leader's success (My supervisor is very good about making time for me when I need it) and failure (My supervisor is not available when I have important matters to discuss) to manage rapport related to subordinate association rights.

\section{Item Refinement}

The 12 items generated were presented to four subject matter experts (SMEs) for suggestions for additional items and refinement of the existing items. All SMEs were scholars who had published research using fundamental constructs from Brown and 


\section{Table 2}

EFA Factor Loadings from Study 1

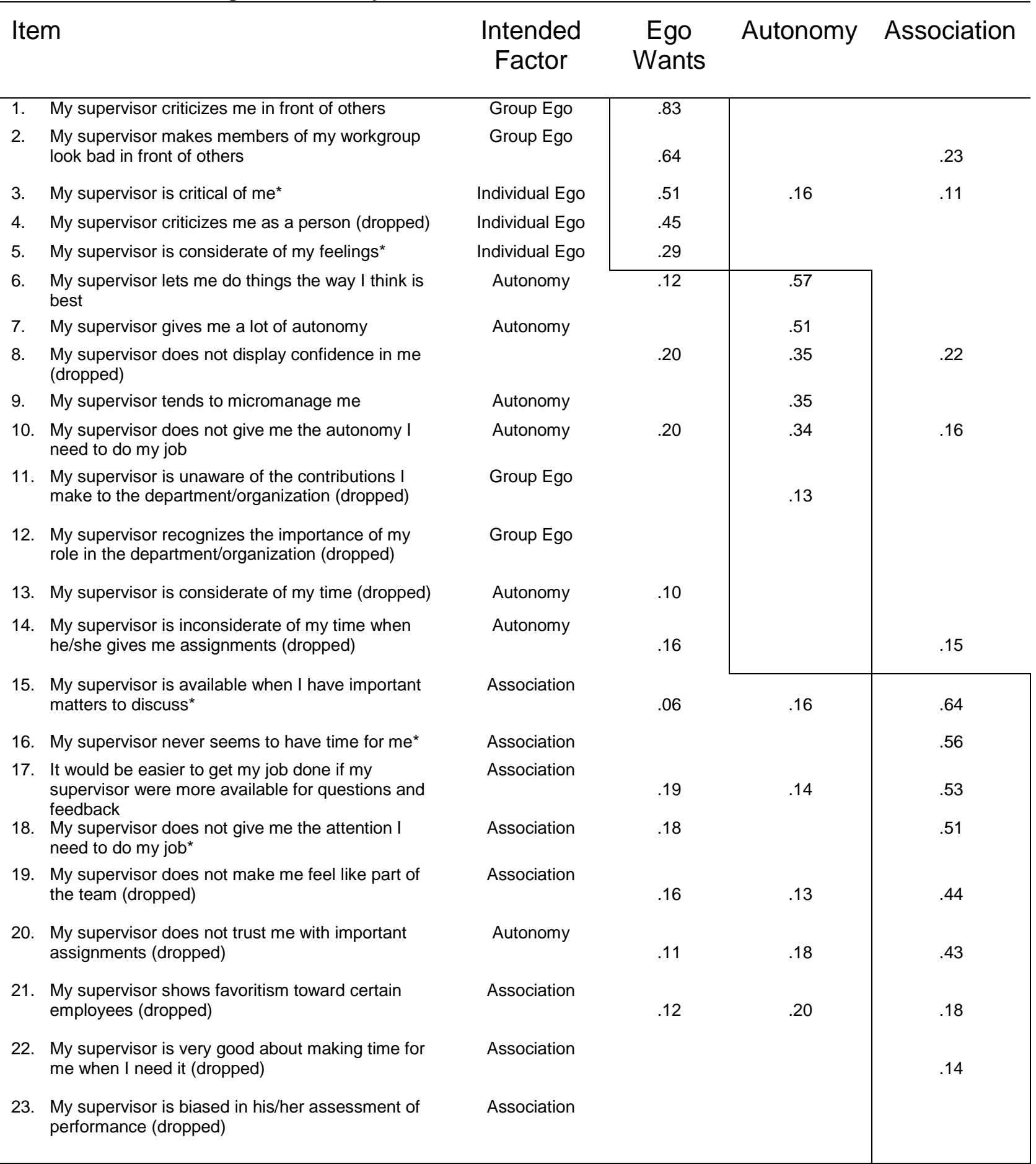

Note: *Item modified for Study 2. Reliabilities for the factors were: Individual Ego (.69), Autonomy (.74) and Association (.72). EFA (oblique rotation) interfactor relationships: Individual Ego/Association (.46), Individual Ego/Autonomy (.36), Association/Autonomy (.30). Loadings less than .10 are suppressed.

Levinson's (1987) seminal work (i.e., ego/autonomy or face wants, politeness, etc.) in 
sociolinguistics--upon which rapport management theory has developed. In addition to modifying the original 12 items, the SMEs offered 11 other items for consideration. The resulting preliminary LRM scale consisted of 23 items (see Table 2) with multiple items representing each of the rapport management dimensions.

\section{Part 2: Scale Evaluation}

The purpose of the first scale evaluation study was to conduct an exploratory test of the factor structure of the 23 initial items.

\section{Scale Evaluation Study 1}

\section{Participants}

Data were gathered from three 300-level management courses $(n=251)$ at a mid-sized public university in the southern United States. Students enrolled in the following courses were asked to complete a survey for extra course credit: Introduction to Organizational Behavior, Introduction to Human Resources Management, and Small Business Management. All research reported in this paper was reviewed by the human subjects committee and received the necessary approvals. Forty-one percent of the respondents were female. Twelve percent of the respondents had less than 1 year of work experience, $18 \%$ had $1-2$ years, $45 \%$ had $3-5$ years, and $24 \%$ had more than 5 years of total work experience. Respondents were asked to refer to a single supervisor for their responses throughout the entire survey. Approximately 39\% of respondents had a relationship with the referent supervisor for less than 1 year, 35\% for 1-2 years, $18 \%$ for $3-5$ years, and $7 \%$ for more than 5 years.

\section{Measures}

As previously described, the 23 items generated in the first study comprised the survey. See Table 2 for the specific wording of the items.

\section{Analysis and Results}

Exploratory factor analysis using the maximum likelihood extraction method with oblique rotation was conducted on these 23 items. Oblique rotation was appropriate due to the anticipated correlation among the factors. The exploratory factor analysis resulted in a solution of three factors accounting for $49 \%$ of the variance.

As can be seen in Table 2, although we developed items to tap each of the four public self-image dimensions suggested by recent rapport management theory (SpencerOatey, 2000), only three factors were extracted by our EFA. Individual and group ego wants did not appear as two separate factors. This result suggests that Brown and Levinson's (1987) original conception of a single category is accurate. The other two factors represented the autonomy and association rights dimensions of public self- 
image as developed by Spencer-Oatey (2000).

We elected to retain four items per dimension. For each factor we selected the four highest loading items with one exception. For ego wants we selected the fifth highest loading item rather than the fourth because we believed that the fourth item was too similar to the others already retained. Thus, in an effort to ensure that we captured the full complement of ego wants, we elected to retain a less redundant item.

In addition, the SME assessment of these items was reviewed to confirm that the items received acceptable agreement for content validity. Items with agreement from three out of four SMEs were retained as is, whereas items in which two of the four SMEs agreed were modified to better reflect the dimension. Changes included adding "In our interactions" to several items in order to increase the focus on behavior within the item and to make the items reflective of leader-subordinate interactions rather than other leader behaviors.

Prior sociolinguistic research (Spencer-Oatey, 2000) suggests that these three dimensions reflect a larger, single construct, and therefore, should be correlated with each other. The correlations between the three dimensions of rapport management, based on the data from study 1 , are presented in Table 3.

Table 3

Factor Correlations from Study 1

\begin{tabular}{lccc}
\hline \multicolumn{1}{c}{ Variable } & Ego & Association & Autonomy \\
\hline Ego & 1 & & \\
Association & $.65^{\star *}$ & 1 & 1 \\
Autonomy & $.46^{\star *}$ & $.37^{\star *}$ & 1 \\
\hline
\end{tabular}

Note: ${ }^{*} \mathrm{p}<.05 ;{ }^{* *} \mathrm{p}<.01$

$\underline{\text { Conclusions }}$

The results of study 1 suggested that the factor structure of the initial LRM items closely approximated the theoretical structure of the rapport management construct and captured 3 dimensions of public self-image using 12 items. However, further testing of the scale to refine the items and confirm the structure was needed.

\section{Scale Evaluation Study 2}

The purpose of study 2 was to test the reduced measure LRM using an organizational sample in order to further validate the factor structure from study 1 .

\section{$\underline{\text { Participants }}$}

Email surveys were sent to a convenience sample of full-time employees in nonacademic settings. Respondents were asked to complete the online survey and 
forward the email request to others. This method resulted in 122 usable responses. The sample was $38 \%$ female. With respect to education, $23 \%$ had some college, $28 \%$ had a four-year degree and $39 \%$ had more than 4 years of college. A total of $29 \%$ of the referent supervisors were female and $23 \%$ of the respondents were employed by public organizations while $77 \%$ were employed in organizations in the private sector. Average respondent age was 41 years with an average of 21 years of work experience. The average length of relationship with supervisor was just under 3 years (34 months).

\section{$\underline{\text { Measures }}$}

The 12-item LRM scale with revisions (presented in Table 4) was sent to participants along with several demographic items.

Table 4

\section{EFA Factor Loadings from Study 2}

Item Ego Autonomy Association

1. My supervisor criticizes me in front of others

2. In our interactions, my supervisor criticizes me

3. My supervisor makes members of my workgroup look bad in front of others

4. In our interactions, my supervisor considers my feelings (dropped due to loading on the wrong factor)

5. My supervisor gives me a lot of autonomy

6. My supervisor tends to micromanage me (dropped due to low factor loading)

$.97 \quad .13$

7. My supervisor lets me do things the way I think is best

8. In our interactions, my supervisor does not give me the attention I need

9. My supervisor takes the time to interact with me when I need him/her to

10. My supervisor has time for my questions and concerns

11. When interacting with my supervisor, I feel that my opinion matters (dropped due to cross loading)

.29

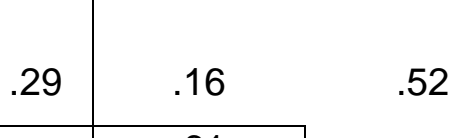

12. It would be easier to get my job done if my supervisor were more available for questions and feedback (dropped due to low factor loading)

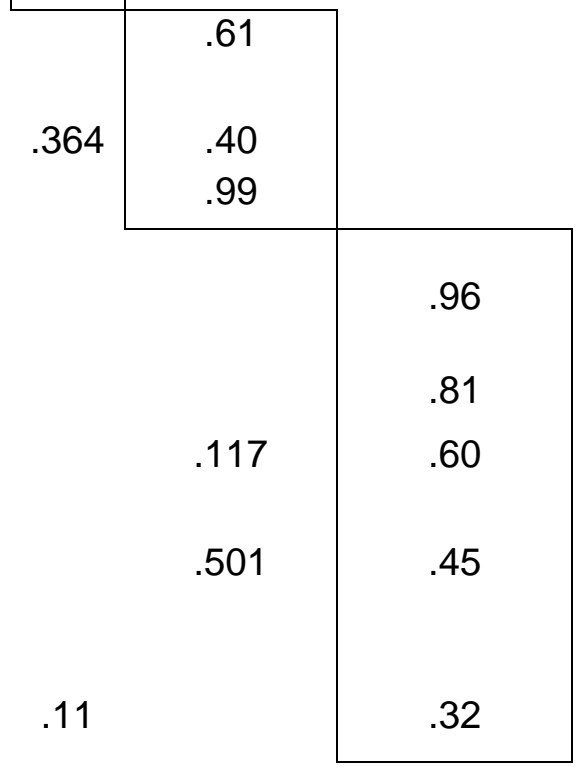

Note: Scale reliabilities are: Ego (.79), Autonomy (.82), and Association (.85). EFA (oblique rotation) interfactor relationships: Ego/Association (.49), Ego/Autonomy (.43), Autonomy/Association (.35). Loadings less than .10 are suppressed. 


\section{$\underline{\text { Analysis and results }}$}

An exploratory factor analysis using maximum likelihood estimation with oblique rotation was conducted on the 12 items. The results of this analysis are presented in Table 4. Based on the results from this sample, several revisions were made to the measure. First, items 6 and 12 failed to load on any factor greater than .4 and were dropped from the pool. In addition, item 11 cross loaded on two factors, and was dropped from the pool. Finally, item 4 loaded on the association factor rather than ego wants, its intended factor, and was dropped from further analysis. After eliminating these four items, the resulting EFA provided a 3 -factor solution with $77 \%$ variance explained.

\section{$\underline{\text { Conclusions }}$}

The results of study 2 provide preliminary evidence of the factor structure of our 8 -item measure of leader rapport management. This scale was used in all remaining studies.

\section{$\underline{\text { Scale Evaluation Study } 3}$}

The final section of this paper serves two important functions: (1) to confirm the structure and dimensionality of the new measure utilizing a third sample and (2) to assess expected versus actual relationships between leader rapport management and other related constructs in order to test the convergent and discriminant validity of the newly developed LRM measure.

\section{$\underline{\text { Participants }}$}

With the assistance of an internal research group from a large financial services firm, electronic surveys were administered to call center employees through the company intranet. A group of 1,200 call center employees were scheduled for 20 minutes to complete the survey. The survey method resulted in 503 useable responses representing a response rate of $44 \%$. Demographic data were added to the spreadsheet by the internal research group using the organization's human resource database. The final spreadsheet was forwarded to the researchers for analysis.

Seventy-four percent of the respondents were female. The organization confirmed that this gender breakdown was representative of the call center population. Average age of respondents was 32 years. The average full-time equivalent work experience was 8 years. Average dyadic tenure (length of relationship with supervisor) was 9 months. Respondents were asked to refer to their present supervisor for their responses throughout the entire survey.

\section{$\underline{\text { Measures }}$}

A 5-point Likert scale (anchors: strongly disagree [1] to strongly agree [5]) was used for responses to all survey items unless otherwise noted. Scale items were summed and then averaged to create an overall number for each construct. Scales were coded such 
that high levels of the constructs are represented by high values.

The 8-item measure of LRM developed through and tested in Studies 1 and 2 was used. Eight items from Oldham and Cummings (1996) were used to measure supportive supervision $(\alpha=.86)$. An example item is "My supervisor helps me solve work related problems." Five items ( $\alpha=.81$ ) from Mayer and Gavin (2005) were used to measure the level of trust toward the supervisor. An example item is "If I had my way, I wouldn't let my supervisor have any influence over issues that are important to me" (reversed). Interactional justice was measured using the Colquitt (2001) nine-item scale $(\alpha=.79)$ that measures the extent to which the respondent's experience reflects attributes of fair interactions. An example item is "My supervisor is candid in his/her communications with me."

Two measures of the leader member exchange were used. The first was the LMX-7 measure (Liden \& Graen, 1980) $(\alpha=.75)$ that assesses how subordinates rate the quality of their relationship with their supervisor with items such as "How well do you feel that your immediate supervisor understands your problems and needs?" These items are evaluated on a 1 to 4 Likert scale with anchors based on the item (e.g., How well do you feel your immediate supervisor recognizes your full potential? Fully, As much as the next person, Some but not enough, or Not at all). The second LMX measure was the 12-item LMX-MDM scale (Liden \& Maslyn, 1998). The scale measures four dimensions of the leader-member relationship (affect, loyalty, contribution, and professional respect) using items such as, "I am impressed with this supervisor's knowledge of his/her job." Cronbach's alpha for the scale is .89 .

\section{Factor structure analysis}

The sample of 503 participants was randomly split in half. Using the first half of the sample, we ran descriptive statistics, variable correlations which are presented in Table 5 , and a confirmatory factor analysis. To confirm that the set of variables in our measure define the rapport management construct (Lomax, 2001), confirmatory factor analysis was conducted on the LRM items using LISREL 8.80 (Joreskog \& Sorbom, 1993). CFA results are presented in Table 6 . Goodness-of-fit indices of the three-factor model were assessed. However, Muliak et al. (1989) noted that alternative models should be considered due to the fact that even good-fitting models may be mis-specified. Alternative one-factor and two-factor models were considered.

Several fit indices were evaluated to determine the fit of the two models. Although a nonsignificant chi-square may provide evidence of model fit, the comparative fit index (CFI; Bentler, 1990), the goodness of fit index (GFI), and the adjusted goodness of fit index (AGFI; Bentler \& Bonnet, 1980) provide a more stable estimation of model fit (good fit $=>.9$ ). A comparison of the fit indices of the measurement models is presented in Table 7. 
Table 5

Mean, Standard Deviation, and Correlations for Scales Used in Study 3

\begin{tabular}{|c|c|c|c|c|c|c|c|c|c|c|c|c|}
\hline & Scale & Mean & SD & 1 & 2 & 3 & 4 & 5 & 6 & 7 & 8 & 9 \\
\hline 1 & Ego Wants & 4.78 & 2.39 & $.77(.76)$ & & & & & & & & \\
\hline 2 & Association Rights & 5.00 & 2.62 & $.47^{\star \star}$ & $.92(.89)$ & & & & & & & \\
\hline 3 & Autonomy Rights & 5.09 & 2.08 & $.21^{\star *}$ & $.27^{* \star}$ & $.69(.80)$ & & & & & & \\
\hline 4 & LRM & 14.87 & 5.1 & $.76^{\star \star}$ & $.83^{\star *}$ & $.59^{\star \star}$ & $.79(.82)$ & & & & & \\
\hline 5 & Perceived Supv Sppt & 22.11 & 9.79 & $.55^{\star \star}$ & $.78^{\star *}$ & $.31^{\star *}$ & $.78^{* *}$ & .96 & & & & \\
\hline 6 & Interactional Justice & 15.37 & 6.78 & $.57^{\star \star}$ & $.79^{\star *}$ & $.34^{\star \star}$ & $.79^{\star \star}$ & $.88^{\star *}$ & .96 & & & \\
\hline 7 & Trust & 19.37 & 6.85 & $.61^{\star *}$ & $.73^{\star *}$ & $.29^{* *}$ & $.76^{\star *}$ & $.84^{* *}$ & $.84^{\star *}$ & .89 & & \\
\hline 8 & LMX7 & 13.15 & 4.52 & $.50^{\star \star}$ & $.66^{\star *}$ & $.31^{\star *}$ & $.68^{\star \star}$ & $.79^{\star *}$ & $.77^{\star *}$ & $.80^{* *}$ & .88 & \\
\hline 9 & LMX-MDM & 22.04 & 7.49 & $.51^{\star \star}$ & $.64^{* *}$ & $.34^{\star \star}$ & $.70^{\star \star}$ & $.78^{\star *}$ & $.77^{\star \star}$ & $.81^{* *}$ & $.85^{\star \star}$ & .92 \\
\hline 10 & Dyadic tenure & 9.38 & 11.41 & -.01 & .00 & -.06 & -.02 & .02 & -.03 & $-.11^{*}$ & -.07 & $-.10^{*}$ \\
\hline
\end{tabular}

Notes:

$N=251 .{ }^{*} p<.05 ;{ }^{* *} p<.01$

LRM $=$ Leader Rapport Management. LMX = Leader-member exchange. MDM = Multi-dimensional measure $\alpha$ on diagonal

Reliabilities for each scale are provided on the diagonal. SqrtAVE for the new scales are in parentheses after the reliabilites. This value should be equal to or greater than the correlations in the same row and column to establish discriminant validity of the new measure (Fornell \& Larker, 1981). 
Table 6

Standardized CFA Factor Loadings for the 8-item LRM Scale from Study 3

Item

Ego Autonomy Association

1. My supervisor criticizes me in front of others

2. My supervisor makes members of my workgroup look bad in front of others

3. In our interactions my supervisor criticizes me

4. In general, my supervisor lets me do things the way I think is best

5. My supervisor gives me a lot of autonomy

6. In our interactions, my supervisor gives me the attention I need

7. My supervisor has time for my questions and concerns

8. My supervisor takes the time necessary to interact with me when I need him/her to do so

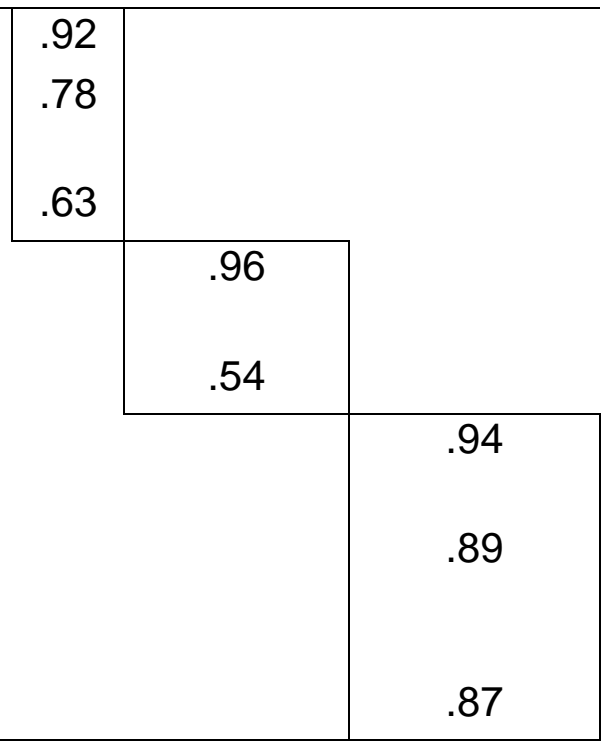

Notes:

Chi-Square $=28.57 ; \mathrm{df}=17 ; p .04 ; \mathrm{RMSEA}=.05 ; \mathrm{CFI}=.99 ; \mathrm{GFI}=.97 ; \mathrm{AGFI}=.94$

The chi-square difference test shows that the two factor model $\left(X^{2}=84.24, \mathrm{df}=19, \mathrm{p}<.01\right)$ is a significant improvement over the one factor model $\left(X^{2}=283.10, \mathrm{df}=20, \mathrm{p}<.01\right)$.

The difference between the two models $\left(X_{\text {diff }}=198.86, \mathrm{df}_{\text {diff }}=1\right.$, critical value $\left.=6.64\right)$ is significant at the .01 level.

Also, the three-factor model $\left(X^{2}=28.57, \mathrm{df}=17, \mathrm{p}<.01\right)$ is a significant improvement over the two factor model $\left(X^{2}\right.$ diff $=$ $55.67, \mathrm{df}_{\text {diff }}=2$, critical value $=9.21$, suggesting that a 3 -dimensional model of leader rapport management is appropriate.

\section{Validity Analysis}

\section{Factorial.}

Factorial validity of the new LRM scale can be assessed by comparing the factor structure in the previous studies, which were based on independent samples (Bagozzi, Yi, \& Phillips, 1991). In all three studies with independent samples, factor analysis results suggest that a three-factor model is most appropriate and provides evidence of the factorial validity of the LRM instrument.

Convergent.

One method of establishing convergent validity is through the assessment of EFA and CFA factor loadings compared with a priori expectations based on theory (Liden \& Maslyn, 1998). The results of all three factor analyses confirmed a three-factor model of rapport management with Spencer-Oatey's individual and group ego dimensions combined to form a single factor. 
Table 7

Comparison of Fit Indices and Chi-Square Difference Tests for Measurement Models

\begin{tabular}{lccccccccrr}
\hline Model & $\mathrm{X}^{2}$ & $\mathrm{X}^{2}{ }_{\text {diff }}$ & $p$ & $d f$ & $d f_{\text {diff }}$ & CFI & GFI & AGFI & $\begin{array}{c}\text { RMSEA (90\% } \\
\text { Confidence Interval) }\end{array}$ & RMR \\
\hline $\begin{array}{l}\text { 1. One } \\
\text { factor }\end{array}$ & 283.10 & & 0.00 & 20 & & .78 & .78 & .60 & $.23(.21-.25)$ & .15 \\
$\begin{array}{l}\text { 2. Two } \\
\text { factor }\end{array}$ & 84.24 & $198.86^{\star *}$ & 0.00 & 19 & 1 & .94 & .92 & .85 & $.12(.09-.14)$ & .11 \\
$\begin{array}{l}\text { 3. Three } \\
\text { factor }\end{array}$ & 28.57 & $55.67^{* *}$ & 0.00 & 17 & 2 & .99 & .97 & .94 & $.05(.01-.08)$ & .03 \\
\hline
\end{tabular}

Note: ${ }^{*} p<.05 ;{ }^{* *} p<.01$

Discriminant.

One method for establishing discriminant validity is to calculate the square-root of the average variance explained (AVE) for the new scales (Fornell \& Larcker, 1981). This value, which we present on the diagonal in Table 5 next to the reliabilities for our scales, represents the variance accounted for by the items that comprise the scale. To demonstrate discriminant validity, this value must exceed the corresponding latent variable correlations in the same row and column. If this condition is met, then we have evidence that the variance shared between any two constructs is less than the average variance explained by the items that compose the scale. As shown in Table 5, this condition is met for the variables used in our study.

Another method of establishing discriminant validity is through the examination of the measure's correlation with constructs that, according to theory or past research, should not be highly correlated (Liden \& Maslyn, 1998). While the LRM measure correlated highly with the dependent variables (see Table 5), correlations between the dimensions of LRM and the dependent variables suggest that the three rapport dimensions are differentially related to supervisor support, interactional justice, trust, and LMX. Evidence of discriminant validity is also provided by the dyadic tenure variable. Although trust and leader member exchange are both related to dyadic tenure, the relationship between rapport management and dyadic tenure should be significantly less than that for LMX and dyadic tenure, as well as for trust and dyadic tenure. Intuitively, it seems that use of rapport management early in the relationship will predict use of rapport management later in the relationship, even if the specific communication behaviors change (Campbell et al., 2003) as the relationship evolves. This would suggest that the use of rapport management is not related to dyadic tenure. Indeed the data from Study 3 demonstrate that only trust was significantly related to dyadic tenure, unlike the LRM scale as a whole, the three dimensions of LMR, and LMX quality. This finding suggests that rapport is distinct from trust because trust develops and grows over time in a relationship, whereas rapport management is not related to length of relationship. 
Criterion-related.

One way to assess the criterion-related validity of the LRM scale is to assess whether the three dimensions are differentially related to various outcomes consistent with theory and research. The second half of the sample was used to run a structural equation model to assess the relationship between the dimensions of rapport management with other constructs (see Figure 1). Correlations presented in Table 5 as well as the results of the model presented in Figure 1 support hypotheses 1-4. Specifically, LRM was positively and significantly related to LMX $(\mathrm{H} 1)$, support $(\mathrm{H} 2)$, trust $(\mathrm{H} 3)$, and justice $(\mathrm{H} 4)$, suggesting that rapport management may help us understand the specific behaviors that underlie their development.

\section{Discussion}

We believe this paper, reporting our development of a scale based on prior theory, using multiple studies with a variety of participants, makes five contributions to management research and suggests a multitude of avenues for future efforts. First, it extends a line a research linking sociolinguistic and leadership theories (e.g., Campbell et al., 2003; Fairhurst \& Chandler, 1989; Morand, 2000). Although leadership research has long acknowledged the importance of relationship building with subordinates, the specific role of a leader's communication behavior within the development of relationships has been less well understood. While this paper focused on LMX theory, LRM deserves further study within the context of many other theoretical frameworks. For instance, effective leader communication behavior (including rapport management tactics) is likely to be dependent on the readiness of a subordinate in any specific situation. Thus, future research might investigate the value of LRM for understanding leader effectiveness within the Situational Leadership Model (Hersey \& Blanchard, 1989).

Another potential link relates to ineffective rapport management and hard interpersonal influence tactics such as a highhanded manner, demands/orders, warnings, and threats (Yamaguchi, 2005; Yukl \& Falbe, 1990). Further research should also continue to explore the effects of demographic issues, such as culture, race, gender, and age in the interpretation of rapport management related behaviors. A different direction for future research would include behavioral observations of leaders and members. Such observational data are typical in sociolinguistic but not in leadership research. These would provide a rich data source to look at rapport management and may be very helpful in refining the LRM measure to include more specific and/or critical leader behaviors. Behavioral observations of rapport enhancing and threatening acts also might allow for more nuanced understanding of the effects these behaviors have on leader-subordinate relationships. 
Figure 1. Relationships between the dimensions of rapport and perceived supervisor support, interactional justice, trust, and the leader-member exchange. All paths are significant.

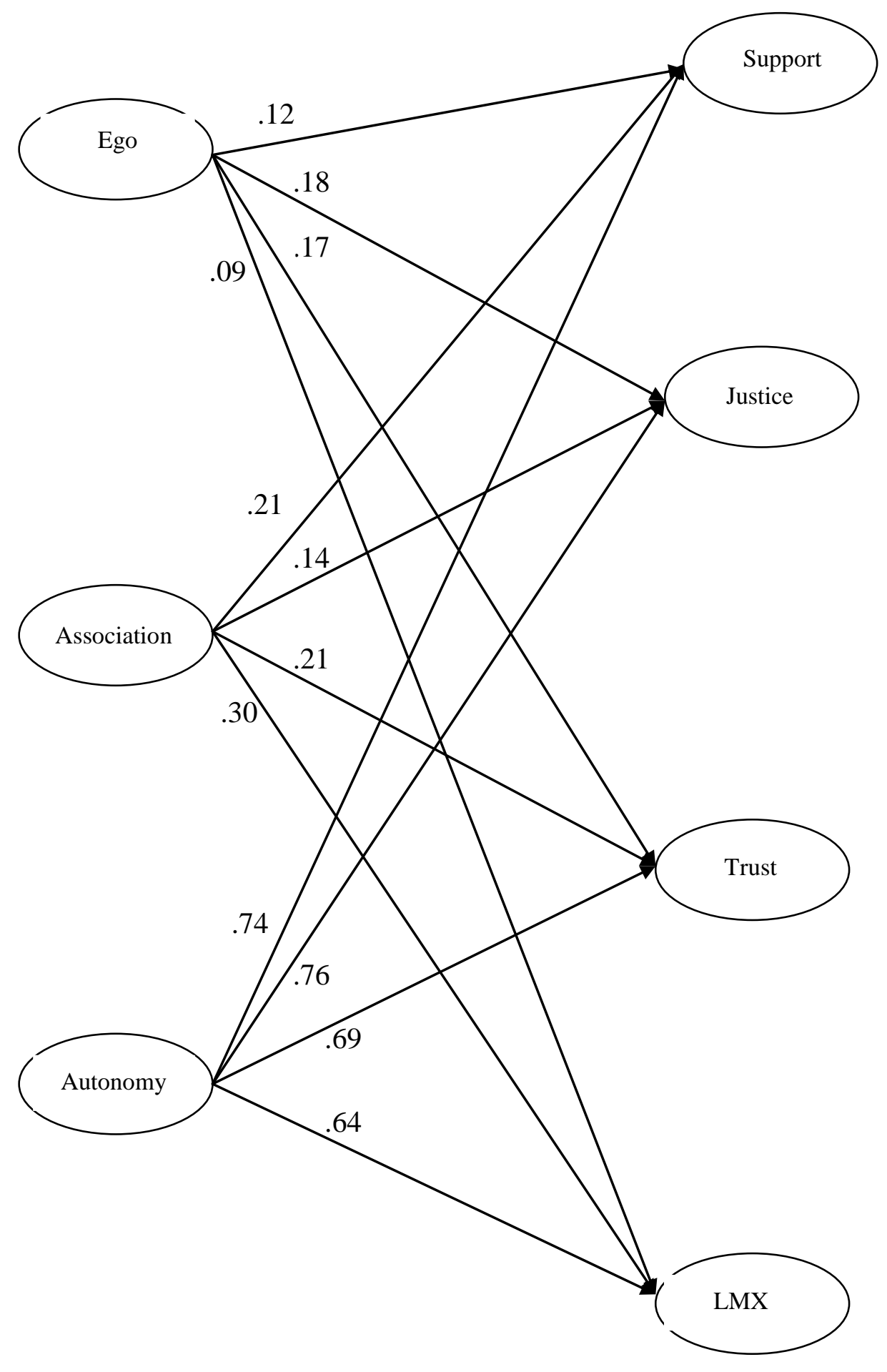


Second and more specifically, this paper extends our understanding of the role of a leader's interpersonal communication behavior and the quality of leader-member exchanges in several ways. Our findings demonstrate that the leader behaviors captured by LRM are correlated with the quality of leader-member relationships captured with two measures of LMX. In particular, this study responds to calls for research on the specific behaviors that influence high quality relationships (Burns \& Otte, 1999; Dienesch \& Liden, 1986) and on subordinate expectations within those relationships (Huang, Wright, Chiu, \& Wang, 2008).

Recent LMX research (Sparrowe, Soetjipto, \& Kraimer, 2006) has demonstrated that the quality of the exchange is important, not only in predicting individual outcomes, but also in subordinate interpretation of leader motives. Sparrowe et al. (2006) found that LMX moderated the relationship between a leader's use of various influence tactics and subordinate helping behaviors. These findings suggest that subordinates' perception of the quality of the relationship with their leaders may serve as a referent in interpreting leaders' motives for the use of various influence tactics. More specifically, the relative effectiveness of soft interpersonal influence tactics, such as a friendly manner, praise, flattery, and sympathy (Yamaguchi, 2005; Yukl \& Falbe, 1990) appears to be explained by their positive effect on the management of rapport. Future research should follow up on this hypothesis.

Finally, the concept of reciprocity has been utilized to differentiate leader-member exchanges (Sparrowe \& Liden, 1997). Sparrowe and Liden placed the dimensions of reciprocity on a continuum based on the interests of each party. On one end of the continuum is negative reciprocity in which both parties behave out of self-interest. In the middle of the continuum is balanced reciprocity in which both parties pursue mutual interests, and on the other end of the continuum is generalized reciprocity in which both parties pursue interests out of concern for the other party. Sparrowe and Liden proposed that early leader member exchanges are characterized by balanced reciprocity, whereas generalized and negative reciprocity are more common in mature leader member exchanges. The effect of rapport management on the development of reciprocity in the relationship would provide a fruitful area for future research. Effective rapport management, through its effect on perceptions of trust and support, may result in the maintenance of balanced reciprocity and the prevention of negative reciprocity and may encourage the growth of generalized reciprocity in leader member relationships. This effect on reciprocity may carry over into other exchanges outside of the leader-member dyad as well. Future research should explore the possibility that rapport management encourages the growth of relationships by increasing the sense of obligation and trust such that both parties become increasingly motivated to pursue mutual goals or other-focused goals rather than self-interest.

Third, this paper suggests a link between a leader's interpersonal communication behavior and several important constructs in management theory. In the studies reported here, LRM was positively and significantly related to supervisor support, trust, and interactional justice. LRM may also be related to organizational commitment. Recent studies to determine the predictors of organizational commitment ( $\mathrm{Ng}$, et al., 
2006) have found continued support for Rousseau's (1998) assertions that management practices that reinforce perceptions of organizational membership and demonstrate concern are important for enhancing organizational commitment. One way of increasing employee's commitment to the organization may be through the selection and training of leaders who are attuned to the wants/rights of subordinates and who actively manage those wants/rights through rapport management techniques, thereby demonstrating concern for employees and increasing the likelihood that subordinates feel valued. Further research to investigate the links between a leader's effective use of rapport management tactics and employee commitment may be a valuable addition to the field. In addition, LRM may be interesting within the context of emotional intelligence because threats to rapport are known to induce anger (Campbell et al., 2007).

Fourth, the scale developed in this study can be used to further investigate the relationships among the three LRM dimensions and perceived supervisor support, interactional justice, trust, and LMX. As one example, our study found leader management of autonomy rights in interactions with subordinates is the strongest predictor of all four constructs. This preliminary finding also supports previous LMX research which suggests that employees who have a higher quality exchange receive and perhaps feel entitled to more time and attention from their leader (Erdogan \& Liden, 2002). Because we provide only correlational results here, further research is needed to better understand any causal effects.

Fifth, this study refines rapport management theory by providing evidence from multiple samples that a three-dimensional rather than four-dimensional (Spencer-Oatey, 2000) or two-dimensional (Brown \& Levinson, 1987) model is appropriate. It seems likely that individual and group ego wants were not judged as separate constructs because subordinates experience all such wants at the individual level. Theoretical support for this inability is found in social identity theory (SIT: Tajfel \& Turner, 1986). SIT posits that individuals have multiple selves, including a personal self as well as selves that correspond to group memberships. The multiple selves have equal standing, which makes it difficult, if not impossible, for the individual to separate violations of individual ego wants from group ego wants. Our findings have particular implications for the need to address racism, sexism, and other forms of group identity threats as these threats are not quantifiably different from personal threats. We should note it is possible that our finding may be a measurement artifact of the LRM scale. However, we believe this is unlikely as the original list of items were developed carefully and specifically to represent both individual-level and group-level ego wants. The other two factors we identified confirm the individual-level autonomy rights and group-level association rights dimensions of public self-image.

\section{Applications of the LRM Scale for Leadership Development}

In addition to its research contribution, we want to note the more practical contributions of the LRM scale. We have successfully used it for individualized leadership development. Given the overwhelming propensity of managers to overestimate the quality of their relationships with subordinates (Gerstner \& Day, 1997), collecting 
perceptions of subordinates is essential for leadership development. LRM results, even based on administration to only a few subordinates, help to identify the specific areas of rapport management that should be the focus of development activities. For instance, in one recent case, LRM results showed that, while the leader successfully managed members' ego and association needs, members felt she did not support their autonomy needs; in contrast, the leader initially thought her weakness was lack of assertiveness. Needless to say, the LRM results were critical in helping the leader become a more effective communicator and relationship builder. In our experience, individual leaders have very different weaknesses. For example, in another recent case, LRM results showed that the leader mentioned above needed to communicate in a way that increased member autonomy to enhance rapport, while a different leader needed to manage rapport by increasing support for association and decreasing member autonomy because he had a large number of inexperienced subordinates. Finally, LRM results seem to us to be especially useful when combined with LMX results establishing relationship quality. In another recent case, a leader's communication behavior with an in-group member was clearly more effective in managing rapport than his behavior with a mid-group member. We believe the LRM scale provides what Molinsky and Margolis (2005) call for: a practical means of identifying the perceived behavioral strengths and weaknesses of leaders as they communicate difficult messages to subordinates.

\section{Limitations}

We see two primary limitations to the research reported here. First, Study 1 utilized a student sample and asked respondents to use information from present or past leadermember relationships. Many cognitive psychology studies have assessed the biased nature of memory (Wirtz, Kruger, Scollon, \& Diener, 2003). This bias is introduced when subordinates are asked to recall past supervisors. However, variability in the responses from Study 1 would indicate that this potential bias was not a problem. The effects of this problem would be very limited in Studies 2 and 3, as participants were asked to respond based on interactions with their current manager. Second, the sample used in Study 3 was limited to call center employees in a single organization. Although this sample provides useful information for studying the relationships among constructs in this study, the generalizability of the results to other employee populations that differ on a variety of characteristics (job autonomy, complexity and frequency of interactions with the leader, etc.) is limited. In addition, organizational representatives reported that survey participants found a number of questions on the survey to be too negative about leaders. This may indicate potential for respondent bias. The nature of the survey may increase the probability of response bias as well. Respondents were guaranteed confidentiality of results, but the survey was not anonymous because employee data were matched to survey responses by internal research personnel. Both of these factors may contribute to response bias and may have decreased the response rate.

\section{Conclusion}

Communication is a critical skill for twenty-first century managers because it impacts a number of important factors in the workplace. And the increasingly global nature of the 
workplace makes communication even more challenging. Current rapport management theory suggests that managers should be aware of situations that could be rapport threatening to subordinates and adjust their communication behavior or style accordingly in order to achieve higher quality relationships with subordinates. To understand more about this theory and to test it empirically, a measure of leader rapport management was needed. The LRM measure developed and tested in the current study will be helpful in furthering our understanding of how employees perceive their leader's ability to maintain three aspects of subordinates' public self-image, their ego wants, autonomy rights, and association rights, during interaction. The measure can also aid leaders in improving relations with subordinates by identifying perceived behavioral strengths and weaknesses for managing each dimension of rapport.

\section{References}

Ambrose, M. L., \& Schminke, M. (2003). Organization structure as a moderator of the relationship between procedural justice, interactional justice, perceived organizational support, and supervisory trust. Journal of Applied Psychology, 88(2), 295-305.

Bagozzi, R. P., Yi, Y., \& Phillips, L. (1991). Assessing construct validity in organizational research. Administrative Science Quarterly, 36(3), 421-458.

Basch, J., \& Fisher, C. (2000), "Affective events-emotion matrix: A classification of work events and associated emotions." In N. Ashkanasy, C., Hartel, \& W. Zerbe. (Eds.), Emotions in the workplace: Research, theory and practice (pp.36-48). Westport, CT: Quorum Books.

Bentler, P. (1990). Comparative fit indexes in structural models. Psychological Bulletin, 107(2), 238-246.

Bentler, P., \& Bonnet, D. G. (1980). Significance tests and goodness of fit in the analysis of covariance structures. Psychological Bulletin, 88(3), 588-606.

Bies, R. J., \& Moag, J. S. (1986). Interactional justice: Communication criteria of fairness. In R. J. Lewicki, B. H. Sheppard, \& M. H. Bazerman (Eds.), Research on negotiation in organizations (pp. 43-55). Greenwich, CT: JAI Press.

Blake, R. R., \& McCanse, A. A. (1991). Leadership dilemmas-grid solutions. Houston, TX: Gulf Publishing.

Brown, P., \& Levinson, S. A. (1987). Politeness: some universals in language usage (Vol. 4). Cambridge, MA: Cambridge University Press.

Burns, J. Z., \& Otte, F. L. (1999). Implications of leader-member exchange theory and research for human resource development research. Human Resource Development Quarterly, 10(3), 225-247.

Campbell, K. S. (2006). Thinking and interacting like a leader: The TILL system for interpersonal effectiveness. Chicago, IL: Parlay Press.

Campbell, K. S., White, C. D., \& Durant, R. (2007). Necessary evils, (in)justice, and rapport management. Journal of Business Communication, 44(2), 1-26.

Campbell, K. S., White, C.D., \& Johnson, D. E. (2003). Leader-member relations as a function of rapport management. Journal of Business Communication, 40(3), 170-194.

Clampitt, P. G., \& Downs, J. D. (1993). Employee perceptions of the relationship 
between communication and productivity: A field study. Journal of Business Communication, 30(1), 5-28.

Cohen, J. (1960). A coefficient of agreement for nominal scales. Educational and Psychological Measurement, 20(1), 37- 46.

Colquitt, J. (2001). On the dimensionality of organizational justice: A construct validation of a measure. Journal of Applied Psychology, 86(3), 386-400.

Delahoussaye, M. (2001a). Leadership in the 21st century. Part one. Training, 38(8), 50-59.

Delahoussaye, M. (2001b). Leadership in the 21st century. Part two. Training, 38(9), 6072.

Dienesch, R. M., \& Liden, R. C. (1986). Leader-member exchange model of leadership: a critique and further development. Academy of Management Review, 11(3), 618-634.

Eisenberger, R., Stinglhamber, F., Vandenberghe, C., Sucharski, I. L., \& Rhoades, L. (2002). Perceived supervisor support: Contributions to perceived organizational support and employee retention. Journal of Applied Psychology, 87(3), 565-573.

Erdogan, B., \& Liden, R. C. (2002). Social exchanges in the workplace: A review of recent developments and future research directions in leader-member exchange theory. In L. L. Neider \& C. A. Schriesheim (Eds.), Leadership: A volume in the research in management series (pp. 65-114). Greenwich, CT: Information Age Publishing.

Fairhurst, G. T., \& Chandler, T. A. (1989). Social structure in leader member interaction. Communication Monographs, 56(3), 215-239.

Fiedler, F. E. (1967). A theory of leadership effectiveness. New York, NY: McGraw-Hill.

Fornell, C., \& Larcker, D. (1981). Evaluating structural equation models with unobservable variables and measurement error. Journal of Marketing Research, 18(1), 39-50.

Gerstner, C. R., \& Day, D. V. (1997). Meta-analytic review of leader-member exchange theory: correlates and construct issues. Journal of Applied Psychology, 82(6), 827-844.

Goffman, E. (1959). The presentation of self in everyday life. Garden City: Doubleday.

Goffman, E. (1967). Interaction ritual: Essays on face-to-face behavior. Garden City, NY: Random House.

Graen, G. (1976). Role making process within complex organizations. In M. Dunnette (Ed.), Handbook of industrial and organizational psychology (pp. 1201-1245). Chicago: Rand McNally.

Graen, G., \& Cashman, J. (1975). A role-making model of leadership in formal organizations: A development approach. In J. G. Hunt \& L. L. Larson (Eds.), Leadership Frontiers (pp. 143-165). Kent, OH: Kent State University Press.

Graen, G., Liden, R. C., \& Hoel, W. (1982). Role of leadership in the employee withdrawal process. Journal of Applied Psychology, 67(6), 868-872.

Graen, G., Novak, M. A., \& Sommerkamp, P. (1982). The effects of leader-member exchange and job design on productivity and satisfaction: Testing a dual attachment model. Organizational Behavior and Human Performance, 30(1), 109-131.

Graen, G., \& Uhl-Bien, M. (1995). Relationship-based approach to leadership: 
Development of leader-member exchange (LMX) theory of leadership over 25 years: Applying a multi-level multi-domain perspective. Leadership Quarterly, 6(2), 219-247.

Greenberg, J. (2004). Stress fairness to fare no stress: Managing workplace stress by promoting organizational justice. Organizational Dynamics, 33(4), 352-365.

Gremler, D., \& Gwinner, K. (2000). Customer-employee rapport in service relationships. Journal of Service Research, 3(1), 82-104.

Hersey, P., \& Blanchard, K. (1989). Management of organizational behavior: Utilizing human resources, ( $5^{\text {th }}$ ed.). Englewood Cliffs, NJ: Prentice Hall.

Hinkin, T. (1995). A review of the scale development practices in the study of organizations. Journal of Management, 21(5), 967-988.

House, R. J. (1971). A path-goal theory of leader effectiveness. Administrative Science Quarterly, 16(3), 321-338.

Huang, X., Wright, R., Chiu, W., \& Wang, C. (2008). Relational schemas as sources of evaluation and misevaluation of leader-member exchanges: Some initial evidence. The Leadership Quarterly, 19(3), 266-282.

Hughes, R. L., Ginnett, R. C., \& Curphy, G. J. (2009). Leadership: Enhancing the lessons of experience, $\left(6^{\text {th }}\right.$ ed.). Boston, MA: McGraw-Hill Irwin.

Joreskog, K., \& Sorbom, D. (1993). LISREL 8: Structural equation modeling with the SIMPLIS command language. Lincolnwood, IL: Scientific Software International, Inc.

Kiewitz, C. (2002). The work anger model (WAM!): An inquiry into the role of anger at work. (Doctoral dissertation, The University of Alabama 2002). Dissertation Abstracts International, Section A, Humanities and Social Sciences, 63(5-A), 1904.

LaBahn, D. W. (1996), Advertiser perceptions of fair compensation, Confidentiality and rapport. Journal of Advertising Research, 36(2), 28-37.

Lagace, R. R. (1990). Leader-member exchange: Antecedents and consequences of the cadre and hired hand. The Journal of Personal Selling and Sales Management, 10(1), 11-19.

Leung, K., Tong, K. K., \& Ho, S. S. Y. (2004). Effects of interactional justice on egocentric bias in resource allocation decisions. Journal of Applied Psychology, 89(3), 405-415.

$\mathrm{Li}, \mathrm{A}$., \& Butler, A. B. (2004). The effects of participation in goal setting and goal rationales on goal commitment: An exploration of justice mediators. Journal of Business and Psychology, 19(1), 37-51.

Liden, R. C., \& Graen, G. (1980). Generalizability of the vertical dyad linkage model of leadership. Academy of Management Journal, 23(3), 451-465.

Liden, R. C., \& Maslyn, J. M. (1998). Multidimensionality of leader-member exchange: An empirical assessment through scale development. Journal of Management, 24(1), 43-72.

Liden, R. C., Wayne, S. J., \& Stilwell, D. (1993). A longitudinal study on the early development of leader-member exchanges. Journal of Applied Psychology, 78(4), 662-673.

Lomax, R. (2001). An introduction to statistical concepts for education and behavioral sciences. Mahwah, NJ: Erlbaum. 
Masterson, S. S., Lewis, K., Goldman, B. M., \& Taylor, M. S. (2000). Integrating justice and social exchange: The differing effects of fair procedures and treatment on work relationships. Academy of Management Journal, 43(4), 738-748.

Mayer, R., \& Davis, J. (1999). The effect of the performance appraisal system on trust for management: A field quasi-experiment. Journal of Applied Psychology, 84(1), 123-136.

Mayer, R., Davis, J. \& Schoorman, F. (1995). An integrative model of organizational trust. Academy of Management Review, 20(3), 709-734.

Mayer, R., \& Gavin, M. (2005). Trust in management and performance: Who minds the shop while the employees watch the boss? Academy of Management Journal, 48(5), 874-888.

McAllister, D. (1995). Affect and cognition-based trust as foundations for interpersonal cooperation in organizations. Academy of Management Journal, 38(1), 24-59.

Meyer, J., Stanley, D., Herscovitch, L., \& Topolnytsky, L. (2001). Affective, continuance, and normative commitment to the organization: A meta-analysis of antecedents, correlates, and consequences. Journal of Vocational Behavior, 61(1), 20-52.

Mintzberg, H. (1975). The manager's job: Folklore and fact. Harvard Business Review, 53(4), 49-61.

Molinsky, A., \& Margolis, J. (2005). Necessary evils and interpersonal sensitivity in organizations. Academy of Management Review, 30(2), 245-268.

Morand, D. (2000). Language and power: An empirical analysis of linguistic strategies used in superior-subordinate communication. Journal of Organizational Behavior. 21(3), 235-248.

Mueller, B. H., \& Lee, J. (2002). Leader-member exchange and organizational communication satisfaction in multiple contexts. Journal of Business Communication, 39(2), 220-244.

Muliak, S. A., James, L. R., Van Alstine, J., Bennett, N., Lind, S., \& Stilwell, C. D. (1989). An evaluation of goodness of fit indices for structural equation models. Psychological Bulletin, 105(3), 430-445.

Ng, T. W. H., Butts, M., Vandenberg, R. J., DeJoy, D. M., \& Wilson, M. G. (2006). Effects of management communication, opportunity for learning, and work schedule flexibility on organizational commitment. Journal of Vocational Behavior, 68(3), 474-489.

Nystrom, P. C. (1990). Vertical exchanges and organizational commitment of American business managers. Group \& Organization Studies, 15(3), 296-312.

Oldham, G., \& Cummings, A. (1996). Employee creativity: Personal and contextual factors at work. Academy of Management Journal, 39(3), 607-634.

Pincus, J. D. (1986). Communication satisfaction, job satisfaction, and job performance. Human Communication Research, 12(3), 395-419.

Quinn, R. E., Hildebrandt, H. W., Rogers, P. S., \& Thompson, M. P. (1991). A competing values framework for analyzing presentational communication in management contexts. Journal of Business Communication, 28(3), 213-232.

Riketta, M., \& Van Dick, R. (2005). Foci of attachment in organizations: A meta-analytic comparison of the strength and correlates of workgroup versus organizational identification and commitment. Journal of Vocational Behavior, 67(3), 490-510.

Rousseau, D. (1998). Why workers still identify with organizations. Journal of 
Organizational Behavior, 19(3), 217-233.

Rupp, D. E., \& Cropanzano, R. (2002). The mediating effects of social exchange relationships in predicting workplace outcomes from multifoci organizational justice. Organizational Behavior and Human Decision Processes, 89(1), 925-946.

Schriesheim, C. A., Castro, S. L., \& Cogliser, C. C. (1999). Leader-member exchange (LMX) research: A comprehensive review of theory, measurement, and dataanalytic practices. The Leadership Quarterly, 10(1), 63-113.

Schriesheim, C. A., Neider, L. L., \& Scandura, T. A. (1998). Delegation and the LeaderMember Exchange: Main effects, moderators, and measurement issues. Academy of Management Journal, 41(3), 298-318.

Snavely, W. B., \& McNeill, J. D. (2008). Communicator style and social style: Testing a theoretical interface. Journal of Leadership and Organizational Studies, 14(3), 219-232.

Sparrowe, R. T., \& Liden, R. C. (1997). Process and structure in leader-member exchange. Academy of Management Review, 22(2), 522-552.

Sparrowe, R. T., Soetjipto, B. W., \& Kraimer, M. L. (2006). Do leaders' influence tactics relate to members' helping behavior? It depends on the quality of the relationship. Academy of Management Journal, 49(6), 1194-1208.

Spencer-Oatey, H. (2000). Rapport management: A framework for analysis. In H. Spencer-Oatey (Ed.), Culturally speaking: Managing rapport through talk across cultures (pp. 98-120). New York, NY: Wellington House.

Spencer-Oatey, H. (2002). Managing rapport in talk: Using rapport sensitive incidents to explore the motivational concerns underlying the management of relations. Journal of Pragmatics, 34(5), 529-545.

Thompson, M., \& Heron, P. (2005). The difference a manager can make: Organizational justice and knowledge worker commitment. The International Journal of Human Resource Management, 16(3), 383-404.

Tubbs, A., \& Hain, T. (1979). Managerial communication and its relationship to total organizational effectiveness. Paper presented at the Annual meeting of the Academy of Management, Atlanta, GA.

Tajfel, H., \& Turner, J. C. (1986). The social identity theory of inter-group behavior. In S. Worchel and L. W. Austin (Eds.), Psychology of Intergroup Relations (pp. 276293). Chicago, IL: Nelson-Hall.

Tannenbaum, R., \& Schmidt, W. H. (1973). How to choose a leadership pattern. Harvard Business Review, 51(3), 162-168.

Yamaguchi, I. (2005). Interpersonal communication tactics and procedural justice for uncertainty management of Japanese workers. Journal of Business Communication, 42(2), 168-194.

Yukl, G., \& Falbe, C. M. (1990). Influence tactics and objectives in upward, downward, and lateral influence attempts. Journal of Applied Psychology, 75(2), 132-140.

Wheeless, L. R., Wheeless, V. E., \& Howard, R. D. (1984). The relationships of communication with supervisor and decision-participation to employee job satisfaction. Communication Quarterly, 32(3), 222-232.

Whetton, D. A., \& Cameron, K. S. (1995). Developing management skills, (3 ${ }^{\text {rd }}$ ed.). New York, NY: Harper Collins.

Whitener, E., Brodt, S., Korsgaard, M., \& Werner, J. (1998). Managers as initiators of 
trust: an exchange relationship framework for understanding managerial trustworthy behavior. Academy of Management Review, 23(3), 513-530.

Wirtz, D., Kruger, J., Scollon, C., \& Diener, E. (2003). What to do on spring break? The role of predicted, on-line, and remembered experience in future choice. Psychological Science, 14(5), 520-524. 